\title{
Enhancement of the enzymatic hydrolysis of fines from recycled paper mill waste rejects
}

\author{
Byeong C. Min, B. V. Bhayani, V. S. Jampana and B. V. Ramarao* ${ }^{*}$
}

\begin{abstract}
Background: A significant fraction of short fibers commonly called "reject fines" is produced while recycling wastepaper at paper mills producing linerboard. These fines are usually rejected into the solid waste stream that further requires land filling and poses environmental problems. The major component of these rejects is cellulose that can be a potential source of fermentable sugars for biofuels, bioplastics or other products. Therefore, a feasible process for converting these reject fines into sugars can profit the paper mills by producing value for their waste products while simultaneously mitigating their adverse environmental impact by avoided solid waste. Additionally, the sugar feedstocks can be used to reduce fossil carbon contributing to the sustainability of the industry.

Results: Enzymatic conversion of rejects fines from paper mills was achieved using commercial cellulases from Trichoderma reesei. The presence of mineral particles along with the cellulosic fines was found to have potent inhibitory effects on enzyme hydrolysis. The mineral particles are kaolin and calcium carbonate and originate from the fillers used in the wastepaper. The adsorption of the cellulase onto these mineral components was measured and quantified by the slope of the adsorption isotherm. The application of a nonionic surfactant Tween-80, decreased the adsorption of cellulase and this improved the hydrolysis yield of sugars.

Conclusions: Enzymatic hydrolysis of rejects from recycled paper mills is feasible and provides a source of sugars for biofuels and bioplastics. However, the presence of mineral particles can be detrimental to this bioconversion. Calcium carbonate which occurs as a filler in waste paper shows high adsorption affinity to the cellulase enzymes and thus reduces the available enzyme for cellulolysis. This can be remedied by the application of surfactants which preferentially occlude to the mineral surfaces and thus increase enzyme availability in solution. The non-ionic surfactant, Tween-80, shows the best hydrolysis enhancement at a dosage of $3 \%$ based on the dry weight of the biomass.
\end{abstract}

Keywords: Enzymatic hydrolysis, Calcium carbonate, Recycled paper, Surfactants, Rejects, Fillers, Cellulase adsorption

\section{Background}

Rising oil prices, unstable supply and the demand for sustainable environmental friendly energy sources have increased the interest in research and development of biomass resources for fuels such as bio-ethanol. Carbohydrates are a natural resource commonly available as lignocellulosic biomass that can be hydrolyzed into sugars to be further converted via fermentative or

*Correspondence: bvramara@esf.edu

Department of Paper and Bioprocess Engineering, SUNY College

of Environmental Science and Forestry, Syracuse, NY 13210, USA thermochemical processes into useful products (Zhang 2008; Arora et al. 2015). Among the important products that can be derived are ethanol (cellulosic), butanol and similar advanced fuels, platform chemicals such as acetone, furfural, levulinic acid, gamma valerolactone and bioplastics such as polyhydroxy butyrates or valerates (Zhang 2008; Singh et al. 2008; Galbe and Zacchi 2002; Bhuwal et al. 2014). These products are a substitute for fossil fuels or starch-based carbohydrates, thus providing an alternate sustainable resource. The plastics are biodegradable and thus are beneficial to the environment in comparison to petrochemicals and their derivatives (Kale

\section{望 Springer}

(c) 2015 Min et al. This article is distributed under the terms of the Creative Commons Attribution 4.0 International License (http:// creativecommons.org/licenses/by/4.0/, which permits unrestricted use, distribution, and reproduction in any medium, provided you give appropriate credit to the original author(s) and the source, provide a link to the Creative Commons license, and indicate if changes were made. 
et al. 2007). Cellulosic biomass is a promising material for bio-energy that avoids the usage of corn and other food grains and thus avoids the necessity of competing with edible sugars. One good source of cellulosic biomass is the waste rejects from recycled linerboard mills which manufacture packaging paper from old corrugated containerboard (OCC).

Repeated recycling of pulp decreases the length of fibers which become shorter and stiffer, losing their ability to bond within the paper sheet. At a certain stage, their net contribution to the sheet becomes negative and they need to be rejected. These short fibers known as fines are recovered from the wastewater stream and typically sent to landfills. The solid residue can also be applied for land use or animal bedding (Scott and Smith 1995; Monte et al. 2009; He et al. 2009; Likon and Saarela 2012). However, the fines can be a very useful resource for sugar production because they are predominantly composed of cellulose which could be converted into glucose and other monomeric sugars. Currently, some paper companies pay $\$ 25-\$ 80 /$ (wet) ton for disposal of the fines (Scott and Smith 1995; Villanueva and Wenzel 2007; Laurijssen et al. 2010). Besides their cost advantage, the supply of fines from paper mills is fairly homogeneous and thus there is minimal influence of seasonal- or weatherrelated supply challenges compared to other agricultural biomass (Villanueva and Wenzel 2007; Laurijssen et al. 2010).

A number of different processes including incineration, gasification and pyrolysis may be used for treating this waste fines stream (Monte et al. 2009). However, direct hydrolysis of the cellulose into sugars can be particularly attractive due to the simplicity of the process and ready use of the sugar solution after concentration (Wang et al. 2012). These sugars can be used as a feedstock for conversions into biofuels and bioplastics such as polyhydroxy alkanoates or into platform chemicals such as succinic acid, lactic acid, levulinic acid and furfurals (Zhang 2008; Bhuwal et al. 2014; Graf and Koehler 2000; Lark et al. 1997; Kádár et al. 2004) Of the varieties of paper mill fines rejects, those from recycled pulp mills using old corrugated cartons are particularly important. Some modern OCC mills find that rejecting 'inactive' fines into the waste stream can be more profitable than using them in the manufactured product, particularly recycled linerboard. The reject stream thus contains higher cellulosic fines contents and typically lower minerals than deinked pulp rejects in the waste streams of fine papers or tissue mills.

The present study focuses on the enzymatic hydrolysis of OCC fines rejects from a recycled linerboard mill. The objective was to identify a method for and optimize the saccharification of this waste stream to yield fermentable sugars. The effect of enzyme activity (characterized by their FPUs, in terms of the filter paper units of activity of the enzyme, per $g$ of cellulose substrate), and impact of hydrolysis temperature, $\mathrm{pH}$, pulp type and filler composition were also studied. Furthermore, methods of enhancing the enzyme activity and sugar yields by binding the minerals using different surfactants (ionic and nonionic) were studied.

\section{Methods}

\section{Materials}

The fines were procured from a recycled linerboard-manufacturing mill in New York State. Unbleached softwood kraft pulp (USKP), unbleached hardwood kraft pulp (UHKP) and mixtures of fiber and fillers were used for hydrolysis. For comparison purposes, samples of old corrugated cartons were also slushed and used. Pulps were ground and screened through a 200 mesh screen (accepts were less than $75 \mu \mathrm{m}$ in size) using a Wiley mill. The fines were not ground given their small particle size. A sample of microcrystalline cellulose (Avicel) was also used as a reference cellulosic source for hydrolysis.

\section{Fines analysis}

Solid content and ash content were computed according to the National Renewable Energy Laboratory (NREL) Laboratory Analytical Procedure (LAP, NREL/TP-51042627, NREL/TP-510-42622). Enzyme activity was determined by NREL LAP (NREL/TP-510-42628). Particle size and Zeta potential were quantified by a particle size analyzer (90 Plus/BI-MAS, Brookhaven Instruments Co.)

\section{Enzymatic hydrolysis}

The hydrolysis of fines was carried in a medium with a solid to liquid ratio of 1:20 with a cellulase dosage of 5-50 FPU using $20 \mathrm{~mL}$ sodium acetate buffer ( $\mathrm{pH}$ 5). Commercial grade cellulases from Trichoderma reesei ATCC 26921 and Aspergillus sp. (CAS No. 9012-54-8) were obtained from Sigma-Aldrich. The hydrolysis flask was placed in a shaking incubator (Reciprocal Shaking Bath 51221080, Precision Scientific Co., Denver CO) and hydrolyzed at $50{ }^{\circ} \mathrm{C}$ up to $72 \mathrm{~h}$ at $120 \mathrm{rpm}$. Samples were withdrawn to analyze for sugar concentration at different time intervals up to $72 \mathrm{~h}$. The hydrolyzed material was then filtered through $0.1 \mu \mathrm{m}$ filters and the filtrate was analyzed for composition using HPLC (Yasarla and Ramarao 2012; Alves et al. 2010). The hydrolysis yield was calculated gravimetrically with reducing sugars based on the substrate loading.

\section{Effect of fillers}

To determine the effect of filler on hydrolysis yield, synthetic reject mixtures were generated in the laboratory 
using unbleached softwood kraft pulp (USKP) mixed with various proportions of calcium carbonate (in two commonly used forms: ground, GCC, and precipitated, PCC) and kaolin. The filler content was varied to understand the influence of each on hydrolysis yield. The total filler content in this mixture was adjusted to yield comparable filler content levels in the original fines (the proportions of calcium carbonate and kaolin were adjusted to a total of $30 \%$ $(\mathrm{w} / \mathrm{w})$ and the ratio of fillers was varied between 0 and 30 \%) (Lavrykov and Ramarao 2012; Singh et al. 2009).

\section{Effect of surfactants}

Since fillers provide adsorption surfaces for the cellulase enzymes (they are nonproductive in terms of sugar production), inactivation by shielding their surfaces with a suitable surfactant to prevent enzyme adsorption was investigated. Anionic (sodium dodecyl sulfate, Amresco ${ }^{\circledR}$ ), cationic (1-hexadecyl trimethyl ammonium bromide, Alfa Aesar ${ }^{\circledR}$ ) and a nonionic surfactant (Tween80, Amresco $^{\circledR}$ ) were chosen for this purpose.

\section{Enzyme adsorption test}

GCC, PCC and Kaolin were used as substrates to determine their inhibitory potential by cellulase adsorption measurements. Each filler of $1 \mathrm{~g}$ (oven dry basis, OD) was loaded in $100 \mathrm{ml}$ flasks with $20 \mathrm{ml}$ sodium acetate buffer under the same conditions as that of the enzymatic hydrolysis. The range of enzyme loading was 5-50 FPU/g OD substrate and the shaker speed was maintained at $600 \mathrm{rpm}$ for $30 \mathrm{~min}$. After shaking, the mixture was centrifuged at 12,000 rpm for $10 \mathrm{~min} .0 .1 \mathrm{~mL}$ of supernatant was drawn into a polystyrene cuvette $(4.5 \mathrm{~mL}$, Brookhaven Instruments, USA) to quantify protein in supernatant using the Bradford protein assay method by adding $3 \mathrm{~mL}$ Bradford reagent (Sigma-Aldrich B6916, St. Louis, MO, USA) (Bradford 1976). The amount of nonadsorbed enzyme in the supernatant was quantified with UV-Vis Spectrophotometer (Thermo Scientific Genesys 10S, USA) by measuring the absorbance at $595 \mathrm{~nm}$ after reaction time of $20 \mathrm{~min}$. The slope of the adsorption isotherm was applied to determine the affinity of the enzymes to each of the fillers.

$$
[A]=K[E]
$$

where $[A]$ is the adsorbed amount of enzyme on the substrate surface $(\mathrm{g} / \mathrm{g}),[E]$ is the enzyme concentration at adsorption equilibrium $(\mathrm{g} / \mathrm{g})$, and $K$ is the slope of the isotherm (for dilute solutions) (g/g).

\section{Results and discussion}

\section{Hydrolysis of fines, pulps and avicel}

To provide a calibration with suitable controls, we first conducted the hydrolysis of the fines in comparison with a sample of Avicel (microcrystalline cellulose). Figure 1 shows the hydrolysis yield of the Avicel and fines with the cellulase from $T$. reesei. The rate of conversion to sugars was initially high for about $4 \mathrm{~h}$ but then decreased at later times. The rate of hydrolysis for the fines was also high during an initial period lasting about $8 \mathrm{~h}$ and reduced with time. The difference in the hydrolysis rates between Avicel and fines can be explained as being due to several factors. Avicel is pure microcrystalline cellulose with particles of approximately $500 \mu \mathrm{m}$ dimensions. Fines have heterogeneous composition as well as different degrees of crystallinity. Furthermore, they are incorporated with mineral filler which decreases the activity of the enzyme. Hemicelluloses, lignin, ash and other contaminants, also account for the slower hydrolysis rate of the fines. As shown in Table 1, the fines rejects had significant quantities of minerals (represented by the ash content) and other synthetic fibers and plastics which interfered with the hydrolysis.

We also conducted control experiments with a sample of an unbleached kraft hardwood pulp (UKHP: sugar maple) in the never dried state and another sample of an unbleached kraft softwood pulp (UKSP: spruce) obtained as dried laps and reslushed in water. The hydrolysis was conducted with a dosage of $50 \mathrm{FPU}$ of cellulase at $50{ }^{\circ} \mathrm{C}$ for $72 \mathrm{~h}$ and the yields were measured after $72 \mathrm{~h}$. The yields of the Avicel, UKHP, UKSP and the fines sample were 92 (4.5), 92 (1.3), 58 (1.8) and 44 (1.7), respectively. The yields were determined from an assay of the sugars and the numbers in the parentheses represent the standard deviations determined from hydrolysis runs in triplicates. Nearly all the cellulose in Avicel was readily converted into glucose. Similarly, the conversion of the sample of the unbleached Kraft hardwood pulp (UKHP) was extremely high. Unbleached kraft softwood pulp (UKSP) shows lower yields primarily because this pulp was dried and reslushed before enzymatic hydrolysis. The process of drying causes the pulps to hornify, i.e., limits the accessibility of cellulose by reducing the cell wall porosity. Upon reslushing, therefore, a dried pulp fiber will not rehydrate to the same extent as virgin fibers and the cellulases are blocked from entering the crystalline structure (Cao et al. 1999). The maximum hydrolysis yield was around $44 \%$ of OD (oven dry mass basis) fines and was found at $50 \mathrm{FPU}$ of the enzyme. The maximum hydrolysis yield was the same at 100 FPU but is not shown here.

\section{Hydrolysis with surfactants}

Some solutions had to be considered to improve the enzyme efficiency for fine hydrolysis process because of the cost contribution of enzyme to sugar conversion from lignocellulosics (Klein-Marcuschamer et al. 2012). The 


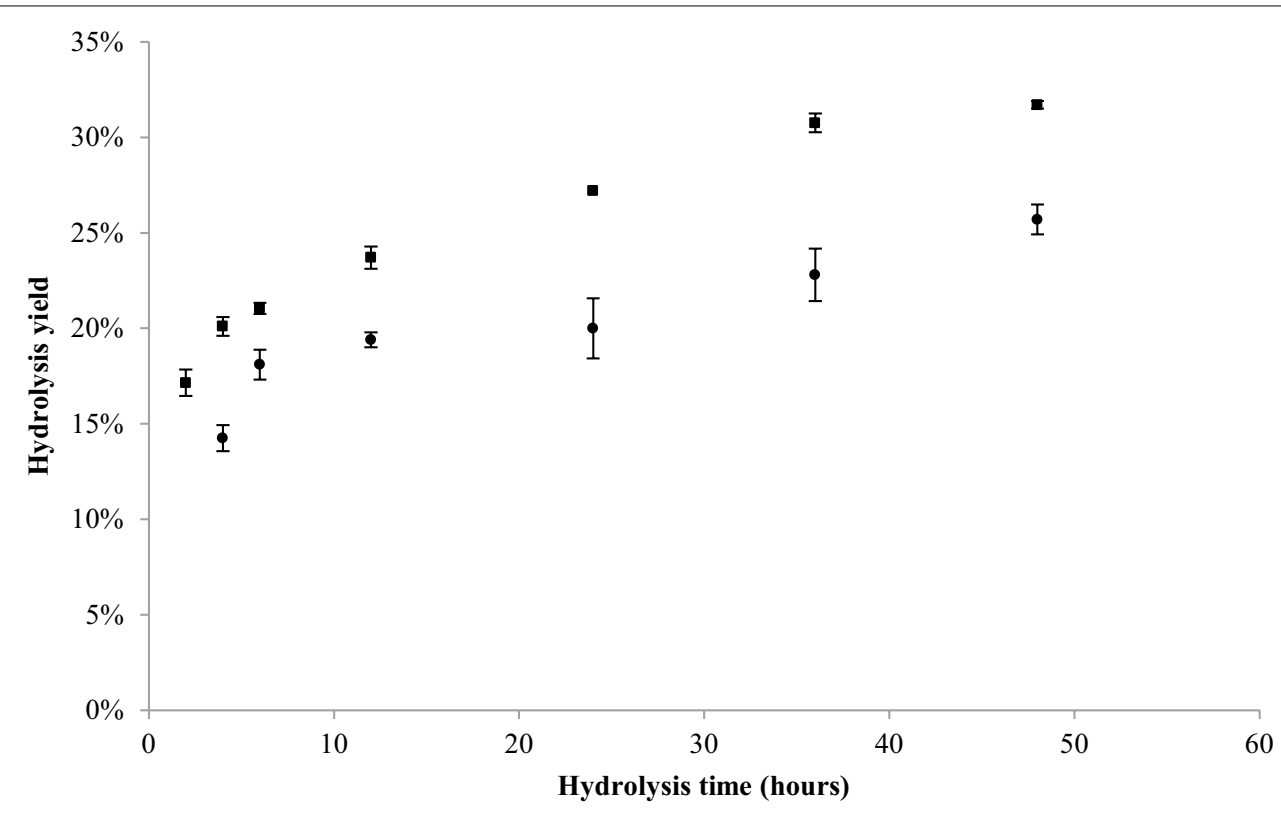

Fig. 1 Hydrolysis kinetics of Avicel (filled square) and fines (filled circle) with 10FPU of T. reesei cellulase. The yield was determined with the weight of reducing sugars from substrate

Table 1 Characteristics of fines rejects from OCC paper mill

\begin{tabular}{lll}
\hline $\begin{array}{l}\text { Fines (rejected fines containing } \\
\text { fillers and contaminants) }\end{array}$ & Value & Unit \\
\hline $\mathrm{pH}$ & $6.5-7$ & \\
Solid content & 52 & $\%$ \\
Particle size & $3-100$ & $\mu \mathrm{m}$ \\
Zeta Potential & $(-) 9$ & $\mathrm{mV}$ \\
Cellulose & 30 & $\%$ (by mass) \\
Hemicelluloses & 10 & \\
Lignin & 4 & \\
Fats & 5 & \\
Ash & 41 & \\
Others (plastics, synthetic fibers, & 10 & \\
Other organics) & & \\
\hline
\end{tabular}

enzyme dosage of $50 \mathrm{FPU}$ for the maximum hydrolysis yield is too high to produce sugars from fines economically since other researchers reported that enzyme less than 10 FPU is sufficient to reach the highest conversion yields of pretreated corn stover, bleached hardwood and softwood pulp, or copy papers (Chen et al. 2012; Roche et al. 2009). We conducted an analysis of fine constitutions and properties to determine the presence of any inhibitory components that may cause inactivation or otherwise hinder the hydrolysis of cellulose in these fines. Table 1 shows an analysis of the fines in terms of their mineral and lignin compositions as well as other characteristic features. It is interesting to note that the amount of ash, representing minerals as fillers in the original pulp fines, was a significant fraction, consisting $41 \%(\mathrm{~g} / \mathrm{g})$ of the total. We also determined that calcium carbonate $\left(\mathrm{CaCO}_{3}\right)$ composed around half of this ash. Lignin was also present in the fines at $4 \%$. The particle size of fines was very small and the $\mathrm{pH}$ was close to neutral (6.5-7), but the magnitude of the zeta potential was small $(-9 \mathrm{mV})$.

The presence of significant mineral particles can reduce the yield of sugar by interference with the action of the enzymes. Most often, this can take the form of simple competitive adsorption of the enzymes reducing the net activity in solution. The impact of mineral fillers was demonstrated in the present study by mixing kaolin or calcium carbonate filler with samples of unbleached hardwood kraft pulps and subjecting them to hydrolysis. The hydrolysis yield was measured for several enzyme dosages. The results indicate that calcium carbonate particles have a dramatic impact, reducing hydrolysis yields as compared to kaolin, which was minimally active.

It may be possible to prevent the interference of hydrolysis by mineral particles by adsorbing a competitive molecule such as a surfactant. Calcium carbonate generally has cationic surfaces whereas charges on kaolin platelets are anionic on the basal surfaces. Kaolin particle edges also show positive charges within a narrow $\mathrm{pH}$ range around neutrality. Thus, adsorption of ionic or nonionic 
surfactants could compete and block enzyme adsorption and inactivation by these minerals. We tested the performance of three kinds of surfactants affecting the hydrolysis. Table 2 shows the yield results for the different kinds of surfactants. The effect of anionic and cationic surfactant on enzymatic hydrolysis yield using 20 FPU of $T$. reesei was not significant. Nonionic surfactant Tween-80 improved hydrolysis yield significantly.

\section{Impact of nonionic surfactant on mineral fillers}

A synthetic 'waste rejects' fines sample was prepared in the laboratory by grinding USKP pulp and mixing it with different proportions of $\mathrm{CaCO}_{3}$ and Kaolin. The effect of the addition of the surfactant was determined with these 'synthetic' mixtures. The proportions of fillers in synthetic fines were to imitate the composition of OCC mill rejected fines. Cellulase enzyme dosage levels were varied from 5 to $50 \mathrm{FPU}$. Table 3 shows results for the yield at different enzyme dosages for different types of mixtures of USKP with mineral particles. A number of interesting features can be observed. Substrate A refers to pure pulp fines without any mineral filler. It is seen that the hydrolysis yield of pulp containing fillers increased with addition of $3 \%$ of the Tween-80. It appears that increasing enzyme dosage increased the yield for enzymolysis of unbleached kraft pulp samples (at $48 \mathrm{~h}$, taken to be the ultimate or equilibrium value). It appears that when the unbleached kraft pulp in its pure form (i.e., not as a mix with mineral

Table 2 Effect of surfactant ( $3 \%$ dosage per $1 \mathrm{~g}$ of fines) on the enzymatic hydrolysis yield

\begin{tabular}{lcccc}
\hline Surfactants & None & $\begin{array}{l}\text { Anionic } \\
\text { (SDS) }\end{array}$ & $\begin{array}{l}\text { Cationic } \\
\text { (CTAB) }\end{array}$ & $\begin{array}{l}\text { Non-ionic } \\
\text { (Tween-80) }\end{array}$ \\
\hline $\begin{array}{c}\text { Hydrolysis } \\
\text { yield (\%) }\end{array}$ & $20( \pm 3.3)$ & $19( \pm 2.4)$ & $20( \pm 4.1)$ & $33( \pm 3.1)$ \\
\hline
\end{tabular}

Enzyme loading $20 \mathrm{FPU} / \mathrm{g}$ (OD fines). Numbers in parenthesis give the standard deviation fillers) was used, hydrolysis was very effective and yields as high as $60 \%$ were obtained (for high enzyme loadings of $50 \mathrm{FPU})$. The addition of the surfactant boosts the yields and accelerates the saccharification kinetics significantly. When the $\mathrm{CaCO}_{3}$ and kaolin fillers were included with the UKSP ( 15 and $15 \%$, by weight, respectively), the hydrolysis decreased dramatically. The addition of the surfactant resulted in a significant boost to the hydrolysis yield. As the case of substrate type $C$ shows, the presence of kaolin in the same amount (i.e., $30 \%$ ) does not result in as large a decrease in hydrolysis yield as it does for PCC. As the results in the last row show, the presence of $30 \%$ PCC particles decreases the yield from a maximum of $60.7 \%$ for the pure pulp to $43.3 \%$. If this was kaolin, however, the reduction in yield is much less significant, showing that it is the $\mathrm{CaCO}_{3}$ component in the PCC form that is most inhibitory of the enzyme activity.

Besides providing surfaces for competitive and nonproductive, i.e., non-hydrolyzing sites for enzyme adsorption, the $\mathrm{CaCO}_{3}$ could perform as an inhibitor in other important ways. For example, the presence of $\mathrm{CaCO}_{3}$ alters the $\mathrm{pH}$ from the optimal value for hydrolysis and $\mathrm{Ca}^{2+}$ ions could bind to the enzymes and neutralize their charges, thus changing their conformation and size in solution.

To investigate this further, enzyme adsorption experiments were conducted with the mineral particles themselves separately and the results are shown in Fig. 2 and in Table 4. In this case, three different mineral particles were chosen, PCC known as precipitated $\mathrm{CaCO}_{3}, \mathrm{GCC}$, ground $\mathrm{CaCO}_{3}$ and kaolin all of which are widely used as fillers in fine papers in the industry. As is apparent from Fig. 2, the nonionic surfactant significantly reduced the affinity of the cellulase enzymes to the mineral surfaces. The slopes of the adsorption curves describing the increase in adsorption per unit change in the enzyme concentration in solution can be taken to represent the affinity of the cellulase to the substrates. PCC has very high enzyme adsorption potential according

Table 3 Effect of fillers and nonionic surfactant on the hydrolysis yield

\begin{tabular}{|c|c|c|c|c|c|c|c|c|c|c|}
\hline \multirow[t]{2}{*}{ Substrate type } & \multicolumn{3}{|c|}{ Additives in USKP ( $g / g$ of OD fine) } & \multicolumn{7}{|c|}{ Enzyme dosage (FPU/g of OD fine) } \\
\hline & Kaolin & PCC & Tween-80 & 5 & 10 & 15 & 20 & 25 & 30 & 50 \\
\hline \multirow[t]{2}{*}{$A$} & 0 & 0 & 0 & 23.0 & 35.7 & 44.3 & 48.9 & 50.9 & 51.5 & 58.1 \\
\hline & 0 & 0 & 0.03 & 27.2 & 41.1 & 47.0 & 52.4 & 56.7 & 57.1 & 60.7 \\
\hline \multirow[t]{2}{*}{ B } & 0.15 & 0.15 & 0 & $\mathrm{n} / \mathrm{a}$ & 10.8 & $\mathrm{n} / \mathrm{a}$ & 23.5 & $\mathrm{n} / \mathrm{a}$ & 41.0 & 57.0 \\
\hline & 0.15 & 0.15 & 0.03 & $\mathrm{n} / \mathrm{a}$ & 17.1 & $\mathrm{n} / \mathrm{a}$ & 36.1 & $\mathrm{n} / \mathrm{a}$ & 46.9 & 60.4 \\
\hline \multirow[t]{2}{*}{ C } & 0.30 & 0 & 0 & 23.3 & 34.2 & 42.1 & 44.1 & 51.5 & 51.9 & 56.6 \\
\hline & 0 & 0.30 & 0 & 1.9 & 8.4 & 8.9 & 10.4 & 16.6 & 20.3 & 43.3 \\
\hline
\end{tabular}

Mixture of fines from ground USKP, PCC and Kaolin. Yield numbers shown as \% 

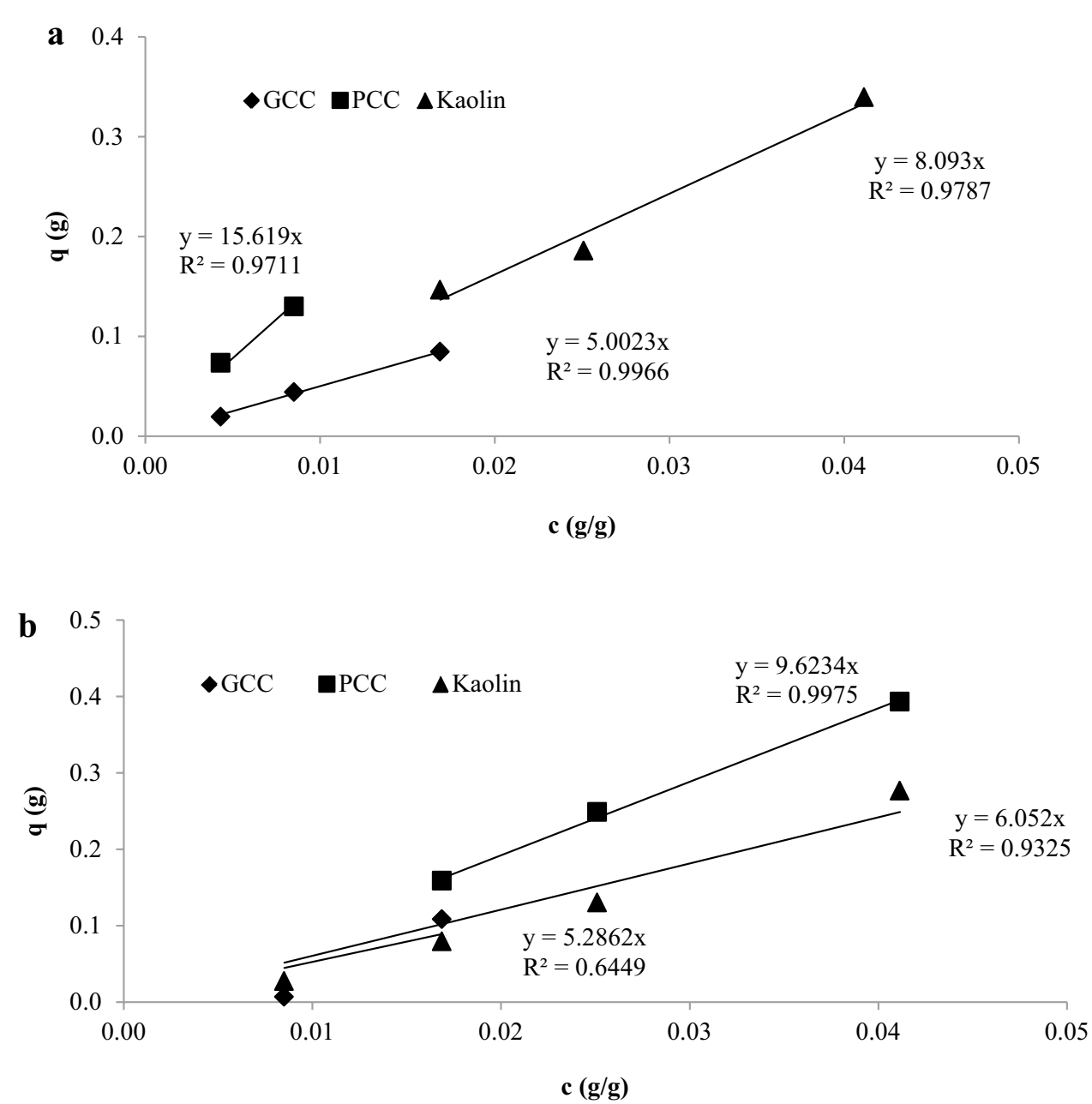

Fig. 2 Enzyme adsorption on GCC (filled diagonal), PCC (filled square), and Kaolin (filled triangle). a Enzyme adsorption amount on fillers depending on initial enzyme concentration. b Comparison of non-ionic surfactant effect (Tween 80, 3 \%) on enzyme adsorption. Slope represents the adsorption affinity $(K)$

Table 4 Equilibrium constant $K_{\text {ad }}$ of GCC, PCC, and Kaolin, with (B) and without $3 \%$ of Tween-80 (A)

\begin{tabular}{llc}
\hline & Fillers & $\boldsymbol{K}_{\mathbf{a d}}(\mathbf{m l} / \mathbf{m l})$ \\
\hline A-Without surfactant & GCC & 5.0 \\
& Kaolin & 8.1 \\
B-With surfactant & PCC & 15.6 \\
& GCC & 5.3 \\
& Kaolin & 6.1 \\
& PCC & 9.6 \\
\hline
\end{tabular}

to equilibrium constant $K_{\text {ad }}$ value. This result indicated that PCC is one of most powerful inhibitors in enzymatic hydrolysis of fines. The surfactant alleviated the inhibitory potential of fillers by reducing enzyme affinity towards the fillers and resulted in increased enzyme availability in solution for the cellulosic fibers.

\section{Optimal surfactant dosage}

The optimal dosage of surfactant was measured for reducing the interference of the fillers. A sample of pulp (UKSP) was taken and mixed with different quantities of filler materials. The hydrolysis yield of UKSP containing $\mathrm{CaCO}_{3}(15 \%)$ was tested with $20 \mathrm{FPU}$ in the range of $0-15 \%$ of the surfactant (Tween-80) dosage (Fig. 3). The yield increased from 8 to $21 \%$ at the surfactant dosage of around $7 \%$. It was observed that the surfactant dosage of lower than $4 \%$ and higher than $10 \%$ did not show any yield increase. It is possible that surfactant adsorption on $\mathrm{CaCO}_{3}$ reaches a maximum at about the $7 \%$ level. Further addition results in the surfactant remaining 


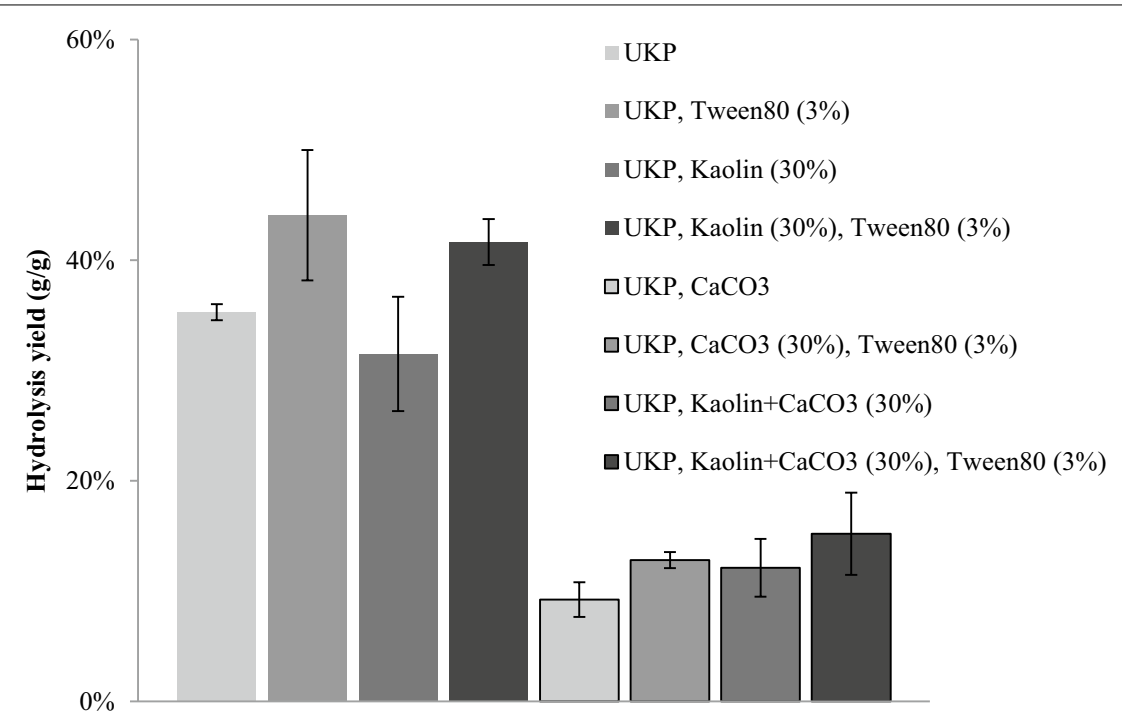

Fig. 3 Effects of fillers (kaolin and calcium carbonate) and nonionic surfactant (Tween 80) on enzymatic (10 FPU, 72 h) hydrolysis yield of artificial fines mixture with milled UKP (softwood, 60 mesh) and fillers

in solution, possibly in micellar form causing deactivation of the enzymes, resulting in steep reductions in yields. Figure 4 shows the impact of the nonionic surfactant on fines hydrolysis at different dosages. In the range of 3-9 \%, surfactant addition appears to improve the yield steadily. However, dosage over $10 \%$ significantly decreases the yield. This impact of the surfactant appears significant only at the low FPU levels. At higher FPU levels of enzyme dosage, surfactant addition does not have a significant impact.

\section{Addition of acid buffer to maintain optimal pH}

The presence of $\mathrm{CaCO}_{3}$ particles in the fines rejects results in a partial neutralization of the acid buffer used for the enzyme hydrolysis. This results in a swing of the hydrolyzing solution $\mathrm{pH}$ towards neutral which reduces the effectiveness of the cellulase. As an example, the addition of a typical $\mathrm{pH} 5$ buffer to the fines increased the $\mathrm{pH}$ of the resultant solution over 6 . Figure 5 shows the hydrolysis yield with varying enzyme dosage when the buffer $\mathrm{pH}$ was unadjusted. The application of the surfactant increased the yields at the lower enzyme dosages. We performed an experiment where the $\mathrm{pH}$ of the solution was maintained at 5 using a $\mathrm{pH} 4$ buffer. This resulted in the solution of $\mathrm{pH} 5$ which was optimal for hydrolysis. The third curve in Fig. 5 exemplifies the increased yield obtained by conducting the hydrolysis at the optimal $\mathrm{pH}$ using this adjustment. As the results show, the lower $\mathrm{pH}$ buffer reinforced ability of enzymatic hydrolysis. A combination of the $\mathrm{pH}$ adjustment and addition of surfactant was effective in increasing enzymatic hydrolysis and minimizing the enzyme dosage.

\section{Impact of drying of fines on hydrolysis}

The hydrolysis of the cellulosic substrates depends strongly on the accessibility of the internal structure of cellulose, but drying of the cellulosic fibers or the fines restricts the access to the hydrolytic enzymes in a process known as hornification. Hornification is the result of drying of pulp fibers and fines that results in a loss of amorphous cellulose and reduction of the internal porosity both resulting in marked reduction of the pulp's hydration capacity, which increases pulp crystallinity (Cao et al. 1999). The impact of hornification of the fines by drying is quantified in the present study (Table 5). The drying effect, i.e., 'hornification' seems to be responsible in reducing the yields by nearly $30 \%$ for both these substrates.

\section{Effect of temperature on hydrolysis}

Temperature can have a strong effect on hydrolysis. Although increased temperature results in faster chemical kinetics, enzymes can be adversely affected by temperature due to changes in their conformation and these large reductions in the enzyme activity can often be observed at higher than optimal temperatures. Commercially available cellulase enzymes are optimally applied at $50{ }^{\circ} \mathrm{C}$. However, since the application of the surfactant alters our process somewhat, it is important to determine whether the optimal temperature for hydrolysis is altered by their presence. Figure 6 shows the effect of surfactant and altered temperatures on the hydrolysis. As can be seen from the yield results at 50 and $55^{\circ} \mathrm{C}$, the reductions at higher temperature are uniformly observed showing 


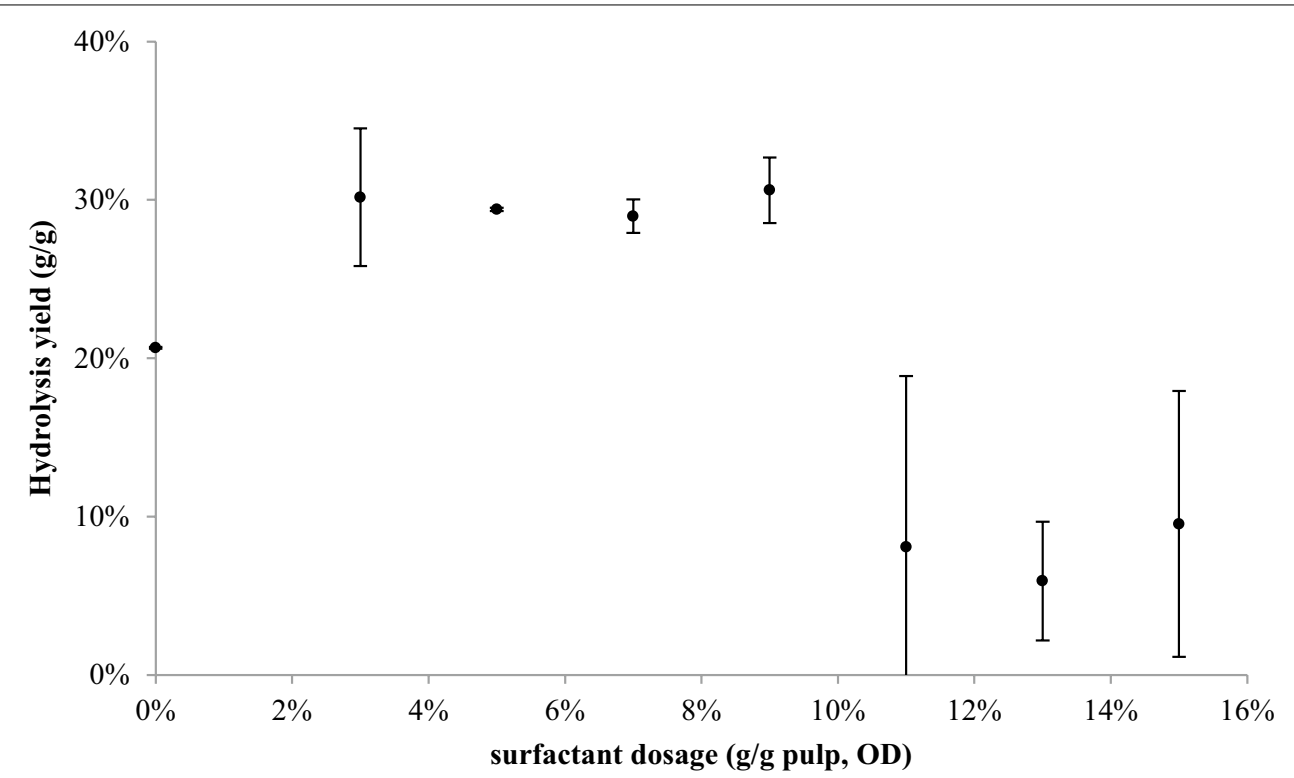

Fig. 4 Hydrolysis yield of fines depending on different Tween 80 dosage with 20 FPU of T. reesei cellulase for $72 \mathrm{~h}$

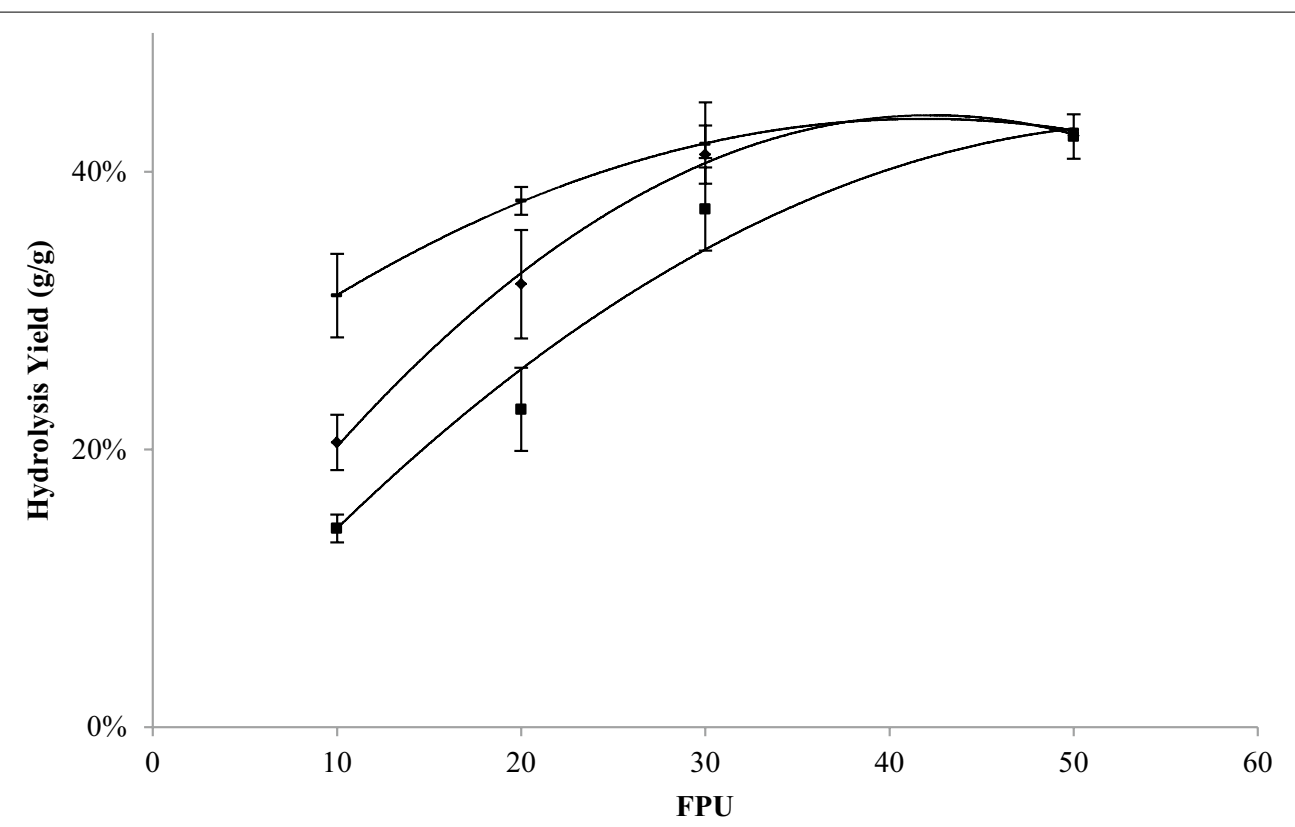

Fig. 5 Combination effect of Tween 80 and pH adjustment on the enzymatic hydrolysis yield for 72 h. Fines only (filled square), fines with of Tween 80 (filled diagonal), fines with Tween 80 and pH adjustment (dash)

Table 5 Drying effect of materials on enzymatic hydrolysis yield

\begin{tabular}{llll}
\hline \multirow{2}{*}{ 25 FPU, 72 h } & \multicolumn{2}{l}{ Hydrolysis yield $(\%, \mathbf{g} / \mathbf{g})$} & \multirow{2}{*}{ Dry effect (\%) } \\
\cline { 2 - 3 } & Non-dried & Dried & \\
\hline Fines & $30.35( \pm 2.7)$ & $21.41( \pm 4.1)$ & -29.5 \\
Unbleached kraft pulp & $92.11( \pm 1.6)$ & $64.06( \pm 0.8)$ & -30.5 \\
\hline
\end{tabular}

that the presence of the surfactant did not change the enzyme's optimal temperature for its catalytic activity. At lower temperature of $40{ }^{\circ} \mathrm{C}$, hydrolysis yield decreased 15-20\% compared to $50{ }^{\circ} \mathrm{C}$ (not shown).

Paper mill rejected fines are a good source of biomass for sugar production given the low lignin content, negative cost, pre-processed nature (which negates 


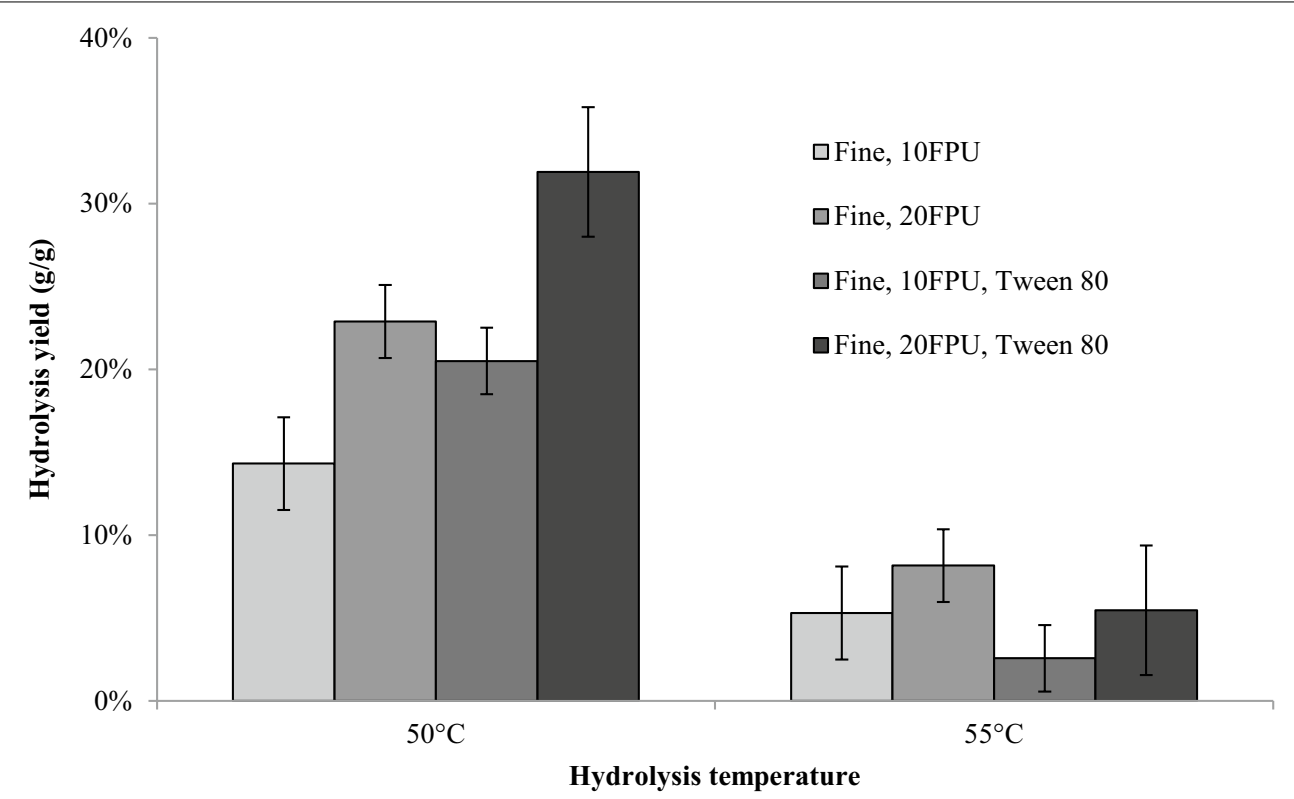

Fig. 6 The effects of surfactant and temperature on fine hydrolysis

requirement of a pretreatment regime) and the large surface area and porous nature of the particles compared to other naturally occurring biomass. The particle size is smaller than typical milled biomass particles (sizes for which are in the sub-millimeter ranges). Approximately, $75 \%$ of the enzymatic hydrolysis yield based on reducing sugars was achieved. The sugar yield of rejected fines is similar to the hydrolysis yield of woody biomass which was reported as 70-90\% for lignocellulosic biomass (Galbe and Zacchi 2002; Sun and Cheng 2002).

The commercialization of "waste cellulosic fiber" based sugar requires deactivation of inhibitory potential of contaminants and ash which includes fillers, calcium carbonate being one of the most powerful inhibitors (Chen et al. 2012). Although ash removal can be attempted, it is not feasible under many industrial circumstances. The filler particles are usually bound to the fibers due to the application of different types of flotation agents in the deinking operations. It renders them difficult to remove by conventional flotation steps. Furthermore, any de-ashing steps using screening methods add to the costs of the process and can prove uneconomical.

\section{Conclusions}

The fines have a potential to produce sugars as a resource of biomass. The main inhibitor of enzymatic hydrolysis fines was $\mathrm{CaCO}_{3}$ which decreases the enzyme activity by enzyme adsorption and $\mathrm{pH}$ increase. Nonionic surfactant Tween-80 improved enzymatic hydrolysis yield of fines in addition to $50 \%$ increase at $10 \mathrm{FPU}$ and reduced enzyme dosage to obtain the maximum hydrolysis yield. A nonionic surfactant was able to significantly reduce the affinity of the fillers to the enzymes. This mechanism appears to be one of the main reasons improving enzymatic hydrolysis yield of pulp. The surfactant application was simple and an economical option to increase profitability and productivity of sugars from waste cellulosic fibers. Using proper $\mathrm{pH}$ buffer was also found to be a critical factor to improve sugar productivity from fines. It was found that addition of surfactants and acid mitigated the inhibitory effect of $\mathrm{CaCO}_{3}$ which has a high inhibitory potential and resulted in decrease of enzyme demanding from $50 \mathrm{FPU}$ to $20 \mathrm{FPU}$ for maximum sugar yield around $95 \%$ (reducing sugars g/g of total sugar in fines). A separation processes to reduce fillers and other contaminants from fines prior to a hydrolysis process can be used to further decrease the enzyme dosage.

\section{Abbreviations}

UKHP: unbleached kraft hardwood pulp (sugar maple, Acer saccharum was chosen here); UKSP: unbleached kraft softwood pulp (spruce was chosen here); OD: oven dry weight; FPU: filter paper units (of cellulase concentration, represented per $1 \mathrm{~g}$ of substrate); OCC: old corrugated cartons (these are extensively recycled all over the world); GCC: ground calcium carbonate, used as filler in many white (fine) paper grades; PCC: precipitated calcium carbonate, used as filler in many paper grades such as copiers, digital printing and other fine and coated paper grades; CTAB: cetyl trimethyl ammonium bromide (cationic surfactant); SDS: sodium dodecyl sulfonate (anionic surfactant); [A]: adsorbed enzyme on fillers or pulp fines or fiber substrates; [E]: enzyme concentration in solution; $K$ : slope of the adsorption isotherm. The adsorption isotherm is assumed to pass through 0,0 . 


\section{Authors' contributions}

$\mathrm{BCM}$ conducted the majority of the experiments and analysis described in this work. BVB assisted the initial fines hydrolysis experiments with different enzymes. VSJ assisted in experimentation and data analysis. BVR initiated the work and supervised it. All authors read and approved the final manuscript.

\section{Acknowledgements}

The support of the New York State Energy Research and Development Authority under grant No. 25922 to SUNY ESF is gratefully acknowledged. The partnership of Minimill Technologies, LLC, Dewitt NY in sourcing mill rejects is also gratefully acknowledged.

\section{Compliance with ethical guidelines}

\section{Competing interests}

SUNY ESF has applied for US patents for the incorporation of surfactants for hydrolysis of reject fines from paper mills. (US Patent Application Nos. 14/212,361; 61/953,152). Avatar Sustainable Technologies LLC, co-founded by the authors (BVB, BVR) has taken a limited time option for possible commercialization.

Received: 27 April 2015 Accepted: 21 September 2015

Published online: 05 October 2015

\section{References}

Alves EF, Bose SK, Francis RC, Colodette JL, lakovlev M, Van Heiningen A (2010) Carbohydrate composition of eucalyptus, bagasse and bamboo by a combination of methods. Carbohydr Polym 82(4):1097-1101

Arora R, Behera S, Sharma NK, Kumar S (2015) Bioprospecting thermostable cellulosomes for efficient biofuel production from lignocellulosic biomass. Bioresour Bioprocess 2(1):1-12

Bhuwal AK, Singh G, Aggarwal NK, Goyal V, Yadav A (2014) Poly- $\beta$ hydroxybutyrate production and management of cardboard industry effluent by new Bacillus sp. NA10. Bioresour Bioprocess 1(1):1-11

Bradford MM (1976) A rapid and sensitive method for the quantitation of microgram quantities of protein utilizing the principle of protein-dye binding. Anal Biochem 72(1):248-254

Cao B, Tschirner U, Ramaswamy S (1999) A study of changes in wet-fiber flexibility and surface condition of recycled fibers. Pap Puu 81(2):117-122

Chen H, Venditti RA, Jameel H, Park S (2012) Enzymatic hydrolysis of recovered office printing paper with low enzyme dosages to produce fermentable sugars. Appl Biochem Biotechnol 166(5):1121-1136

Galbe M, Zacchi G (2002) A review of the production of ethanol from softwood. Appl Microbiol Biotechnol 59(6):618-628

Graf A, Koehler T (2000) Oregon cellulose-ethanol study. An evaluation of the potential for eth-anol production in Oregon using cellulose-based feedstocks report prepared by the Oregon of-fce of Energy Portland, Oregon, USA
He J, Lange CR, Dougherty M (2009) Laboratory study using paper mill lime mud for agronomic benefit. Process Saf Environ Prot 87(6):401-405

Kádár Z, Szengyel Z, Réczey K (2004) Simultaneous saccharification and fermentation (SSF) of industrial wastes for the production of ethanol. Ind Crops Prod 20(1):103-110

Kale G, Kijchavengkul T, Auras R, Rubino M, Selke SE, Singh SP (2007) Compostability of bioplastic packaging materials: an overview. Macromol Biosci 7(3):255-277

Klein-Marcuschamer D, Oleskowicz-Popiel P, Simmons BA, Blanch HW (2012) The challenge of enzyme cost in the production of lignocellulosic biofuels. Biotechnol Bioeng 109(4):1083-1087

Lark N, Xia Y, Qin C-G, Gong C, Tsao G (1997) Production of ethanol from recycled paper sludge using cellulase and yeast, Kluveromyces marxianus. Biomass Bioenergy 12(2):135-143

Laurijssen J, Marsidi M, Westenbroek A, Worrell E, Faaij A (2010) Paper and biomass for energy?: The impact of paper recycling on energy and $\mathrm{CO}_{2}$ emissions. Resour Conserv Recycl 54(12):1208-1218

Lavrykov SA, Ramarao B (2012) Thermal properties of copy paper sheets. Drying Technol 30(3):297-311

Likon M, Saarela J (2012) The conversion of paper mill sludge into absorbent for oil spill sanitation-The life cycle assessment. In: Macromolecular Symposia. Wiley Online Library, pp 50-56

Monte M, Fuente E, Blanco A, Negro C (2009) Waste management from pulp and paper production in the European Union. Waste Manag 29(1):293-308

Roche CM, Dibble CJ, Knutsen JS, Stickel JJ, Liberatore MW (2009) Particle concentration and yield stress of biomass slurries during enzymatic hydrolysis at high-solids loadings. Biotechnol Bioeng 104(2):290-300

Scott GM, Smith A (1995) Sludge characteristics and disposal alternatives for the pulp and paper industry. In: TAPPI International Environmental Conference. TAPPI Press, pp 269-269

Singh S, Mohanty AK, Sugie T, Takai Y, Hamada H (2008) Renewable resource based biocomposites from natural fiber and polyhydroxybutyrate-covalerate (PHBV) bioplastic. Compos A Appl Sci Manuf 39(5):875-886

Singh R, Lavrykov S, Ramarao BV (2009) Permeability of pulp fiber mats with filler particles. Colloids Surf A Physicochem Eng Asp 333(1):96-107

Sun Y, Cheng J (2002) Hydrolysis of lignocellulosic materials for ethanol production: a review. Bioresour Technol 83(1):1-11

Villanueva A, Wenzel H (2007) Paper waste-recycling, incineration or landfilling? A review of existing life cycle assessments. Waste Manag 27(8):S29-S46

Wang L, Sharifzadeh M, Templer R, Murphy RJ (2012) Bioethanol production from various waste papers: economic feasibility and sensitivity analysis. Appl Energy 111:1172-1182

Yasarla LR, Ramarao BV (2012) Dynamics of flocculation of lignocellulosic hydrolyzates by polymers. Ind Eng Chem Res 51 (19):6847-6861

Zhang Y-HP (2008) Reviving the carbohydrate economy via multi-product lignocellulose biorefineries. J Ind Microbiol Biotechnol 35(5):367-375

\section{Submit your manuscript to a SpringerOpen ${ }^{\odot}$ journal and benefit from:}

- Convenient online submission

- Rigorous peer review

- Immediate publication on acceptance

- Open access: articles freely available online

- High visibility within the field

- Retaining the copyright to your article

Submit your next manuscript at $>$ springeropen.com 